\title{
The challenge that Confucian filial piety poses for Korean churches
}

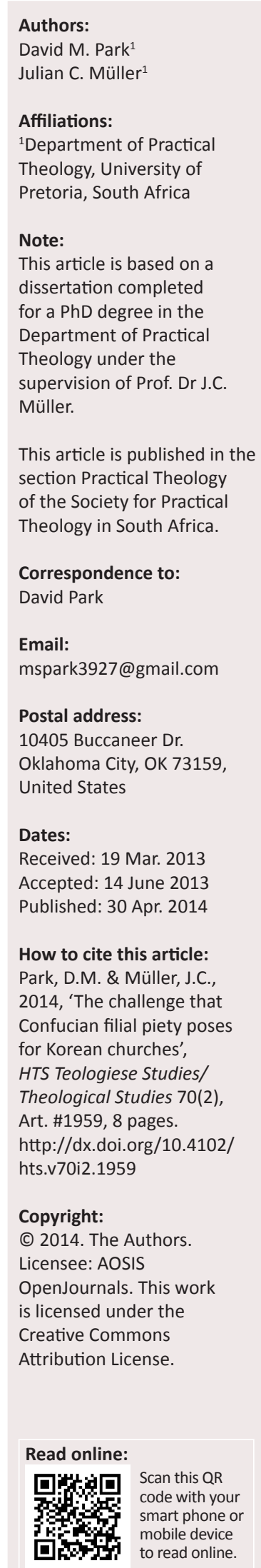

Contemporary ancestor worship is currently practiced around the world in several different forms. However, the essence and practice of ancestor worship varies throughout Asia, Africa, Oceania and Latin America. The context of countries under the influence of Confucianism is very different from that of other countries. Confucianism teaches that ancestor worship is the most prized display of filial piety toward one's dead ancestors. Amongst Asian countries under the influence of Confucianism - specifically China, Japan, Malaysia, Taiwan, Vietnam and Korea - ancestor worship has not only been accepted and propagated as a culture, but it is also considered to be filial piety. Especially the Korean people think that ancestor worship is a very important expression of filial piety, and it is a ritual which they practice regularly during their festive days. What does Confucianism teach about filial piety, and how is ancestor worship practiced? What does the Bible teach about filial piety? Are practical applications of biblical filial piety present in Korean society? Rather than allowing Confucian ancestor worship to take root in Korean society as a traditional Korean heritage, the conclusion is that Korean Christians must make an effort to teach and facilitate biblical filial piety.

\section{Introduction}

Filial piety refers to young children serving or honouring their father and mother, based on the principles of both Confucianism and the Bible. According to Confucianism, filial piety is the most significant and holds the highest virtue of all ethical teachings. The most important classical literature in Confucianism concerning filial piety is Shao Chien ${ }^{1}$ (Book of filial piety). Probably written in the 2nd or 3rd century BC, the Book of filial piety describes how ancient kings and sages practiced the duties of filial-piety rites directed to heaven and to their parents. The concept of filial piety has influenced the history of China for over 2500 years, and it is the stabilising and unifying force of the Chinese family system (Chao 1987:21). A teaching of Confucius, filial piety is emphasised in decidedly Confucian schools. The analects of Confucius (2:5) reports that Confucius said the following with regard to the propriety of ancestor worship when Lord Meng Yi inquired about filial piety: 'When your parents are alive, serve them according to the ritual. When they die, bury them according to the ritual, and make sacrifices to them according to the ritual' (Confucius 1997:6-7). Here, 'ritual' refers to ancestor worship. Ethically, filial piety is the primary virtue, defined as an obligation to serve and honour one's parents in life and to continue so even after their death. It 'originally meant piety to dead parents and ancestors, and the duties owed to them of sacrifice and sustenance' (Parrinder 1983:321).

'The rite of dead ancestors' ${ }^{2}$ in Confucianism entails both a significant attitude and a familial ritual towards death and the afterlife. The ritual teaches that respect for parents and one's elders is the root of humanity and that filial piety includes not only honouring parents whilst they are alive but also practicing ancestral rites for deceased parents (Oldstone-Moore 2002:55-56). Confucians believe that filial piety does not terminate when the parent dies; rather, filial piety continues in the form of funerals and memorial rites after the death of one's parents.

Contrary to Confucian teaching, Korean Protestant Christians cannot agree with ancestral rites nor accept that ancestral rites differ from necrolatry. Filial piety is an important Christian virtue, but worship of the dead is contrary to biblical filial piety. Son (Lee 1988:61) describes the history of Korean Christianity as the 'shedding of blood' because, historically, ancestor worship has resulted in much bloodshed amongst Korean Christians. Since the introduction of Christianity into Korea in 1884, ancestor worship has created conflict and confrontation between Christian and non-Christian family members. Christians traditionally reject the practice of ancestor

1.Shao is the Chinese character 孝, which means '(filial)' or '孝道 (filial piety)'. This character is the combination of two words, 老 ('old person') and 子 ('child'), which means that the child supports the old person. The inner meaning of the Chinese character 'Shao' is the relational perspective of filial piety. Chien is the Chinese character '經', meaning 'scripture'. Shao Chien is written in the form of dialogue on the teachings of filial piety.

2.The terms 'rite of dead ancestors', 'rite of the dead parents', 'ancestral rite', 'ancestor cult', 'ancestor veneration' and 'ancestral practice' have been used by different writers to refer to 'ancestor worship'. 
worship because they believe that the honouring of one's parents entails showing respect for one's living parents rather than adhering to the Confucian rites of worshiping dead ancestors. Protestant Christians believe that ancestor worship is the actual worship of the spirits of one's dead ancestors and not merely the veneration of these ancestors. Thus, Korean Confucians and non-Christians have criticised Christianity as a religion exhibiting a lack of understanding for filial piety.

The main conflict that Confucian filial piety has with Korean Christianity, and the main challenge it poses, is that Confucianism teaches that the worship of dead ancestors is filial piety. In the Bible, honouring parents is demonstrated by showing respect for one's living parents rather than worshiping dead ancestors as prescribed through Confucian rites. According to Ryoo (2000:114-119), the idea in Confucianism that worship of the dead is filial piety has led to confusion and syncretism amongst modern Korean Christians.

Against this background, it is pertinent to ask the following questions: What are the similarities and differences concerning filial piety between Confucianism and Christianity?

\section{Confucian ancestor worship as filial piety}

As demonstrated by its name, ancestor worship refers to direct or indirect worship directed towards dead parents and other ancestors. According to Brown (1969:98), ancestor worship is 'simply acts of propitiation and sacrifices of atonement, which are intended to reconcile, and to bring back into harmonious fellowship the severed kinship'. Ancestor worship is currently practiced in various forms around the world, but Confucian ancestor worship in Korea possesses a very different meaning from ancestor worship in other countries. Confucianism believes that, when ancestor worship is practiced, the dead person's soul returns to the ritual place and eats the sacrifices at that spot.

In Confucian ancestor worship, Confucian worshipers presume that dead ancestors are able to protect their own families, receive sacrifices from their descendants, watch over their own families, bring fortunes to their descendants, help friends and harm enemies and reward the right and punish the wrong. Ancestors are usually considered as requiring continuous attention, and neglecting one's ancestors brings misfortune to the family.

Confucian ancestor worship entails two important functions: (1) to bind together the dead ancestors and living descendants of a family and (2) to bind together the living family members. In Confucianism, dead parents and their living descendants are inseparable (Lee 1988:17). Thus, when people die, they do not lose contact with their lineage but rather remains in the lineage as a household deity. Confucians believe that the dead are actually present at the sacrificial rites performed for ancestor worship, the dead enjoy the offerings and are dependent upon posterity for their fortunes, ancestor worship is prompted by a sense of filial piety, ancestor worship is the most fundamental expression of filial piety, ancestor worship is regarded as a form of filial piety and expression in continued affection for one's dead parents and ancestor worship is regarded as the extension of filial piety beyond the grave. As part of the culture, this concept is a basic practice of the family in the land of Korea.

Confucian ancestor worship consists of the worship of heaven and earth along with the ceremony directed towards Confucius and one's ancestors, which is amongst the various types of Confucian ancestor worship considered by the Koreans as filial piety.

\section{Nine rites of Confucian ancestor worship}

Confucianism entails three major forms of ancestor worship: '(1) the funeral rites, (2) the mourning observances, and (3) the continuing sacrifices to the Manes' (Thompson 1975:47). These three forms of Confucian ancestor worship consist of nine rites, which are practiced in ten steps. The nine rites in which a family performs ancestor worship for their dead ancestors are translated as chesa in Korean. These nine ancestral rites (Ryoo 2000:70-74) are still practiced in South Korea:

- 虞祭 - the rite that is practiced on the funeral day and the rite that is practiced on the second and third days afterwards

- 小祥 - the rite that is practiced on the first anniversary of a person's death

- 大祥 - the rite that is practiced on the second anniversary of a person's death

- 禫祭 - the rite that is practiced on the second month after the second anniversary of a person's death

- 吉祭 - rite that is practiced on the 27 th month after a person's death

- 時祭 - ancestor memorial services performed during each season of the year

- 茶禮 - rites that are practiced four times a year (during the day) on significant holidays like the lunar New Year (Sul) or the Autumn Harvest Festival on the lunar 15th August (Chusuk)

- 忌祭 - a memorial service held at home at midnight on the night before the death day of an ancestor (Ki-il).

These eight rites are intended to commemorate four generations of one's ancestors. The last of these is 墓祭, a memorial service held in front of the grave.

\section{Ten steps in the procedure for Confucian ancestor worship}

The procedure for Confucian ancestor worship consists of ten steps (Choi 1988:38-39), which reveal the theology of Confucian ancestor worship. The ten steps are as follows:

1. The master of a house bows down to an ancestral tablet, which is taken out of the shrine. The ancestor's wood tablet possesses a twofold meaning as the image of an 
invisible soul and as the resting place of the soul so that ancestor worship is not just an action of veneration to one's dead ancestors but rather an encounter with the spirit of one's dead ancestors.

2. He invokes the ancestor's soul by burning incense and pouring liquor into a bowl, which serves as an invitation for the soul of the dead to come.

3. He offers liquor and food in a motion of respect in conjunction with feeling the presence of the soul at the spot. This is a gesture symbolic of sincerity and respect.

4. He reads a ritual prayer in which the soul enjoys the offered sacrifices as a means of expressing affection. The reading of a ritual prayer is conducted in a manner of conversing with the ancestor whilst he or she was alive.

5. Bowls are filled with liquor for the second and third time whilst the prayer is read. This is an expression of the desire that the ancestor will appreciate the sincerity and devotion with which the sacrifice was offered.

6. All family members leave the room to give the ancestor's soul time to enjoy the sacrifices.

7. After a whilst, family members re-enter the room to take away the bowls and to serve tea.

8. The family members bow in order to bid the soul to depart.

9. Someone returns the ancestral tablet to the shrine and burns the paper which was used as the table, designating the closure of the ancestral ritual.

10. Family members and relatives share the liquor and food used for the ancestor worship. The tenth rite is a means of sharing identity with the soul of the dead and of creating improved harmony amongst family members and relatives.

Choi (1988:39) emphasises that the significance of Confucian ancestor worship remains in 'fulfilling one's filial duties by remembering one's ancestors, rewarding the origin, and repaying favours given by ancestors, and not in the enjoyment of a rite by the soul'.

\section{Confucian filial piety}

According to Confucianism, filial piety is mankind's highest and central virtue. Confucian filial piety includes not only honouring living parents but also practicing rites for the deceased parents. Thus, people in Korea have historically practiced ancestor worship as the expression of filial piety ever since Confucianism was accepted as a national religion and as the centre of ethical standards for the Chosun dynasty. During the festive days, many Koreans currently practice the annual traditional custom of ancestor worship as an expression of filial piety to their dead parents.

Filial piety is one of the five Confucian principles, namely Li, Ren, Xiao, Shu and Chung. Li [禮] means appropriate behaviour in all situations, obligatory manners or customs, ceremony, ritual, and propriety. Ren [1] means humaneness, humanity, love to others, human-heartedness or virtue. Xiao/ Hsiao [孝] means filial piety. Shu [恕] means the principle of mutuality or reciprocity and consideration for others.
Chung [忠] means loyalty - especially loyalty, along with reciprocity, filial piety and humaneness (Lewis \& Travis 1991:299-304).

Filial piety is one additional teaching of Confucius. Amongst the collection of Confucius's thirteen classical books, two main Chinese classics deal mainly with filial piety. Hsiao Ching [The book of filial duty] the eleventh classical book, is the book of short conversations on filial piety. The tenth classical book, Confucian analects, is the book of the sayings of Confucius. These books not only teach the doctrines and principles of filial piety, but they also teach the meaning of true filial piety and the lack of filial piety.

\section{Hsiao Ching}

Hsiao Ching [The book of filial duty] (piety), which uses 24 exemplary stories to reveal how filial piety is practiced in one's life, offers the most important aspect of the relationship between filial piety and ancestor worship and further reveals the reality of how important filial piety is to ancestor worship. To Tseng Tzu's question in chapter 7, 'How great is the use of filial duty?' Confucius replied:

Filial duty is the constant doctrine of Heaven, the natural righteousness of Earth, and the practical duty of man. Every member of the community ought to observe it with the greatest care. (The book of filial duty 1908:20)

'The constant doctrine of Heaven' means that filial piety is heavenly filial piety.

\section{The book of the analects of Confucius}

The book of the analects of Confucius (1997) records mainly the statements or conversations between Confucius and his disciples. The analects of Confucius is a collection book which contains the most important sources of information about Confucius, his disciples and his thoughts. Around 400 BC, over 75 years after his death, his disciples wrote this book. Through the book, the teachings of Confucius played a key role in influencing other countries such as Korea, Japan, Malaysia, Taiwan and Vietnam in the development of culture, education and moral standards. This book strongly emphasises filial piety, sacrifices and rites for deceased ancestors. Many passages with regard to filial piety relate to ancestor worship. The emphasis on ancestor worship accompanies the term 'filial piety' in 1:2, 1:6, 1:11, 2:5-8 and 4:18-21.

\section{Biblical filial piety}

The Bible observes and emphasises filial piety as much as does Confucianism. Filial piety is an important biblical teaching, but scriptural filial piety is directed toward one's living parents and not one's deceased parents. The fifth commandment states that one should honour one's mother and father. To honour means to observe filial piety. The Old and New Testaments observe and emphasise filial piety as much as does Confucianism. Biblical filial piety is the first commandment with a promise that it may go well with us and that we may enjoy a long life on earth (Eph 6:2). 
In the Old Testament, the words 'honour' or 'respect', in כבר Hebrew (kabod), originally meant 'to be heavy, to be precious or to be important' in the physical and spiritual sense. In Aramaic, kabod further connotes the double meanings of 'heavy, difficult' and 'respected, honoured'. According to Botterweck (1995:16-17), the verb occurs 114 times in the Old Testament with all the stems: the qal 23 times, the hiphil 17 times, the piel 38 times, the niphal 30 times, the pual 3 times and the hithpael 3 times. Amongst these forms, the piel form relates to filial piety. The piel form is primarily a declarative meaning of 'honour or approve'. The secondary meaning can be more clearly used for filial piety.

The noun form kabed [liver] derives from kabod [heavy] and can denote the liver as a bodily organ. Kabed was developed in considering the concepts of heavy, important and precious, and then finally, it came to mean honour or respect (Botterweck 1995:13-24). To Hebrew parents, it meant that filial piety was considered the most important or heavy-duty practice, intimating that the Hebrew language emphasises filial piety as a basis for the evaluation of the value of a person. The quality and quantity of filial piety correlate with the maturity of a person.

The Pentateuch mentions filial piety on numerous occasions and presents very detailed ways to accomplish filial piety (i.e. Gn 9:20-27; Ex 20:12; Lv 19:3a; Dt 5:16, 21:18-21). Through the relationship that occurred between Ruth and her motherin-law, Naomi, the book of Ruth illustrates the true meaning of biblical filial piety for those living in modern times. The book of Proverbs contains many passages with an emphasis on filial piety (i.e. Pr 1:8, 4:1, 6:20, 10:1, 17:25, 23:22-25).

The New Testament refers to practicing filial piety toward one's parents by using the phrase from one of the Ten Commandments, which is to 'honour your father and mother'. Generally, the Greek term for meaning 'to honour'

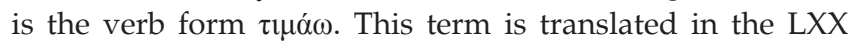
with the Hebrew כבר (kabod). It term includes the practical provision of providing food, drink and even clean clothing for the parents. It connotes the meanings of 'worth', 'satisfaction', 'compensation', 'evaluation', 'respect' and 'honour'. When ascribed to an exalted person, $\tau \mu \alpha \dot{\alpha} \omega$ means 'to honour or to respect'. Jesus not only quotes the Ten Commandments in the four Gospels, but by using the term $\tau \mu \mu \alpha \omega$, he emphasises the commandment to honour parents as a commandment demanding unconditional obedience (Mt 15:4, 19:19; Mk 7:10, 10:19; Lk 18:20). The Apostle Paul quotes the Ten Commandments in his letters. Additionally, Paul uses the term $\tau$ นó $\omega$ in his letters on several occasions to refer to the concept 'to honour' (Eph 6:2; 1 Tm 5:3; Col 3:20; Ac 28:100). Jesus and Paul emphasise that the new people of God are called on to keep these commandments. Additionally, Peter uses $\tau \mu \alpha \dot{\alpha} \omega$ to impart proper respect to everyone and to honour the king in 1 Peter 2:17 (Kittel 1987:178-179).

In 1 Timothy 5:4, Paul uses a special term, $\varepsilon v \sigma \varepsilon \beta \varepsilon \dot{\omega} \omega$, for depicting filial piety. The Korean Bible translates this word precisely as 'filial piety', meaning to be 'reverent', 'respectful' or 'pious' in relationship to God. It refers to the relationship of man to others or to relatives and of man to God. The duty of piety is obligatory as a virtue for all humankind. This word emphasises the conduct of man as a particular manner of life. According to Gloer (2010), 'Religious duty ( $\varepsilon v \sigma \varepsilon \beta \varepsilon v v)$ ' comes from the verb form, $\varepsilon v \sigma \varepsilon \beta \varepsilon \dot{\varepsilon} \omega$, which means:

\begin{abstract}
... both to honor the deity appropriately, that is, 'to worship', and, in an ethical sense, to fulfill one's obligations to the deity. In this case, the religious obligation is to the family, and it is of 'first' importance. It should include 'some repayment to their parents.' (p. 182)
\end{abstract}

It refers to God requiring filial piety as a religious duty in order to show loyalty to families, including one's parents. Paul emphasises that fulfilling one's obligations to one's parents is pleasing to God as a part of fulfilling one's obligation to God.

\section{The origin of Confucianism in Korean history}

Traditionally in Korean history, the idea of Confucian ancestor worship and filial piety has yielded great influence on Korean lifestyles and culture. Koreans have practiced Confucian ancestor worship for a long time. Even though Confucianism was introduced into Korea in 1122 AD, it flourished after it was accepted as a national religion and became the centre of ethical standards for the Chosun dynasty. ${ }^{3}$

Sunggye Yi, the first king of the Chosun Dynasty, adopted Confucianism as his national ideology to justify and solidify his revolutionary dynasty. King Yi forced Confucianism on the people to expurgate the ideal of Buddhism, which was the national religion of the previous Koryo dynasty. During the Chosun dynasty (1392-1910 AD), Korea possessed a typical educational system reflecting Confucian ideals:

... to such an extent that court officials would offer 'royal lectures' to the ruler, reflecting the Confucian ideal that it is an enlightened and cultured monarch who can best serve the people. (Oldstone-Moore 2002:71)

King Sunggye Yi (1392-1398) became the most famous of the kings to develop and expand Confucianism in Korea. King Yi adapted the teachings of Confucianism into the principles of government for the moral basis of the country and to education (Slavicek 2002:73). By that time, Confucianism prevailed throughout Korea, and Confucians built temples in important villages throughout the country in order to worship ancestors and Confucian sages with ostentatious ceremonies and sacrificial offerings (Ro \& Nelson 1995:22). The Yi-dynasty government established many Confucian schools throughout the country and continually taught an ideology of filial piety and ancestor worship. Ancestor worship was practiced as 'a most important national ritual' (Lee 1988:1). Legal documents of the Chosun Dynasty from

3.Confucianism in Korea existed prior to the Chosun dynasty (1392-1910). The scope of this article does not cover the entire history of Korean Confucianism but rather begins from the Chosun dynasty, which has most influenced modern Korean Confucianism. 
1391, 1397, 1402, 1407, 1428 and 1431-1432 reveal several examples of legislating aspects of ancestor rites as a matter of state and public policy. Adams (1995:105) states that '... the 1397 legal code was especially influential in setting in motion the processes that would thoroughly transform Korean society'.

For 500 years, the Chosun Dynasty dominated with the ideas of Confucianism. Lee (1987:69) affirms that the organisation and development of ancestor worship were widespread and were established during the last years of the Koryo Dynasty and throughout the Chosun Dynasty as cultural and sociological functions: 'In spite of its profound religious significance, ancestor worship provides a powerful focus for social organisation among kinsmen, much as the early Confucian reformers intended.' Thus, Confucian ancestor worship imposed upon indigenous customs, and reforms were overwhelmingly successful in Korean society.

Many Korean people currently practice ancestor worship and visit ancestors' graves as an annual traditional custom during the festive days. Typically, ancestral rites are still practiced on the Chinese New Year; the Korean Thanksgiving Day, August 15, and the anniversary of the date that one's ancestor had died. Additionally, Confucians practice autumn and spring sacrifices at the Confucian shrine of the Historic National Confucian Academy in Seoul to honour Confucius and his Chinese and Korean disciples. Additionally, special ceremonies are performed on September 28, Confucius's birthday, in the academy's Confucian shrine and in many ornate Confucian temples located throughout the South Korean countryside.

\section{A challenge of Confucian ancestor worship in modern Korean society}

Since Protestant Christianity was introduced into Korea in 1884, membership of Korean Christian churches have grown to the remarkable number of close to nine million. According to the national population and housing census report of 2005, amongst the entire population of Korea (approximately 47041 434), Protestant Christians comprise 18.3\% (8 616 428), and Confucians comprise $0.2 \%$ (104 575). The question is therefore why Korean Christianity struggle with ancestor worship if $0.2 \%$ of the population is Confucian? The primary reason is that Confucian customs, values and beliefs have historically dominated Korean culture, thought and education. Many Korean people still participate in ancestor worship because the Korean people consider ancestor worship to be a high virtue of filial piety to a dead ancestor. Oldstone-Moore (2002) observes the following concerning Confucian ancestral rites as filial piety in South Korea:

The Confucian heritage in South Korea is still evident in patterns of daily life. The practice of ancestral rites is widespread. An overwhelming percentage of the population, even among those who identify themselves as Christian, practices Confucian rituals and ceremonies, primarily in the form of ancestor veneration. (p. 102)

The veneration of a dead father and mother is not a sin against God from the Confucian perspective. However,
Confucian ancestor worship is not just the memory of the dead father and mother because ancestor worshipers believe that dead people return to the ritual place to partake of the food prepared for them by their descendants. Confucian ancestor worship is not simply a memorial service in honour of the dead. Rather, their sacrifices are offered to the spirits of the dead ancestors. Thus, the challenge of Confucian ancestor worship is not merely a matter of cultural factors; rather, it is a matter of religious beliefs.

Ryoo (2000:123-125) indicates very clearly how the rite of dead parents is a challenge for Korean churches; the survey is a clear indication of the importance of this issue to the Korean Christian community. Following are a few of the survey questions polled of pastors and the results: 'Do you think that the rite of the dead parents presents a problem in your ministry as a pastor?' Seventy-seven percent responded 'yes' and 23\% responded 'no'. Another question was: 'Do you seriously counsel your congregation with regard to the rite of the dead parents?' Ninety-nine percent responded 'yes' whilst $1 \%$ responded 'no'. Lastly, it was asked: 'How do you answer, or what do you recommend to your congregation?' Nine percent responded 'yes' to maintaining the rite whilst $61 \%$ said that it depends on the family situation, and $30 \%$ responded with an absolute 'no'.

Furthermore, Ryoo (2000:141-44) asked lay people about their thoughts about ancestor worship as filial piety. Regarding the rite of the dead parents, $54 \%$ responded by saying that the rites are an important matter to Christians, $8 \%$ stated that it depends on the family situation, and 38\% responded that the rites are not a big problem. When asked about holding the rite of the dead parents in the home, $45 \%$ responded by saying that the rites are a definite problem, 30\% stated the rites are somewhat of a problem, and $25 \%$ indicated the rites were not a problem.

Regarding the rite of dead parents amongst relatives, 33\% of respondents stated that the rites are a problem, $42 \%$ indicated that the rites are somewhat of a problem, and 25\% attested to having no problems. When asked about their reasons for implementing the rite of the dead parents, 53\% of the respondents stated that the rites are an expression of filial piety, 5\% responded that the rites are a way to receive blessings, and $41 \%$ responded that the rites are a good custom. An additional 1\% chose to skip the rite altogether. Amongst the people involved in the survey, some were from families that were entirely Christian whilst others were from families in which only some of the members were Christian (Ryoo 2000:141-44). As the results of Ryoo's survey indicate, amongst Korean Christian families, close to $75 \%$ currently encounter significant or somewhat significant problems with relatives concerning ancestral rites.

These results point out the continued presence of the influence of Confucian ancestor worship as filial piety in Korean Christianity, and even contemporary Korean Christian families are struggling with the matter of ancestor worship. 


\section{Practical applications of biblical filial piety}

Many Korean people think that ancestor worship is a very important expression of filial piety. Furthermore, Korean Roman Catholics accept and practice ancestor worship, and Korean non-Christians consider Roman Catholicism to be the same religion as Protestant Christianity. The decision of Korean Roman Catholics to allow Confucian ancestor worship creates severe conflicts between Korean Protestant Christians and non-Christians.

Thus, should Christians attempt to resolve this issue without compromise by accepting ancestor worship as a cultural practice meant as filial piety by Koreans?

\section{Two categories for the practical applications of biblical filial piety toward living parents}

The Bible emphasises filial piety, which should be practiced by children in various ways. Botterweck (1995:16) reveals that the word 'honor' or 'respect', in Hebrew כבר (kabod), occurs 114 times in the Old Testament as a verb form, and the piel form occurs 38 times in connection to filial piety. In the four Gospels, Jesus emphasises the importance of filial piety more than he does importance of the Old Testament. The distinction of the teaching of Jesus about filial piety is that it is not just words; rather, filial piety refers to performing one's responsibility toward one's parents. Filial piety is not an ideal but rather a practical principle for children. Paul expands the meaning of filial piety in the sense that fulfilling the obligation to one's parents is pleasing to God as a part of fulfilling one's obligation to God (Eph 6:2; 1 Tm 5:3-4; Col 3:20; Ac 28:10).

Chang (1975) proposes a positive attitude by revealing filial piety to modern Christians:

Filial piety is the root of all virtues. It only commences with the respect of parents; it should be culminated in the fear of the Lord, our Father in heaven. (p. 839)

Additionally, Chang (1975) encourages Christians to practice biblical filial piety because:

... faith in God is not in contradiction with, but is rather the ultimate fulfillment of true piety in its fullest sense. Strictly speaking, only a Christian can really know and practice filial piety. (p. 839)

Two categories exist with which to practice biblical filial piety to living parents. One is the active principle whilst the other is the passive principle. The writer suggests to Christians each of the ten fundamental principles of both as practical applications from the passages of the Old and New Testaments.

The ten active fundamental principles of filial piety:

1. Support them on adversities (Gn 47:12; Rt 1:16-17; Jn 19:27).

2. Respect them (Ex 20:12; Dt 5:16).

3. Listen to their instructions $(\operatorname{Pr} 4: 1,4: 13,6: 20-23,15: 5)$.
4. Become proud of them (Pr 10:1, 15:20, 23:24).

5. Bring joy and happiness to them $(\operatorname{Pr} 23: 25 ; 3$ Jn 1:4).

6. Honour them with both word and action (Mt 21:28-31; Lk 2:51).

7. Confess and restart when sinning against them (Lk 15:1820a).

8. Thank them for living under their supervision (Lk 15:2832).

9. Obey them in the Lord (Eph 6:1-2).

10. Succeed to their faith $(2 \operatorname{Tm} 1: 5,3: 15)$.

The ten passive fundamental principles of filial piety:

1. Do not reveal their weak points (Gn 9:18-27).

2. Do not deceive them like Jacob (Gn 27:1-29).

3. Do not curse them (Ex 21:17; Lv 20:9).

4. Do not disgrace their names and family by entering into evil conduct (1 Sm 8:1-3).

5. Do not revolt against them (2 Sm 15:1-6).

6. Do not have rancour toward them when they forsake us (Ps 27:10; Is 49:15).

7. Do not forget their precepts (Pr 4:6).

8. Do not cause them anxiety and uneasiness (Pr 17:25).

9. Do not despise them when they are old ( $\operatorname{Pr} 23: 22)$.

10. Do not steal from their possessions ( $\operatorname{Pr} 28: 24)$.

In order for biblical filial piety to take root in Korean society, Korean Christians continually demonstrate these biblical teachings of the Old and New Testament to their living parents and to nonbelievers.

\section{Christian memorial service as a solution}

According to Ryoo's (2000:152) survey, 11\% of Korean Christians responded by saying that Confucian ancestor worship and the Christian memorial service should be merged, $45 \%$ responded that they should strive for merging, and $42 \%$ indicated that they absolutely should not merge. These findings reveal that, although many attempt to reduce family conflict due to ancestor worship, they do not possess a perfect solution, and the matter of ancestor worship still creates problems amongst family members. As the Bible teaches that filial piety is to be directed toward living parents, Christians practice biblical filial piety as a solution to achieving mutual peace beyond a sense of incongruity of religious ideals and conflicts between regions, generations or social classes in Korean society.

Many Korean churches currently practice Christian memorial services of biblical filial piety as a substitute for ancestor worship as filial piety in Confucianism. These services are called Choodoyeebae. Choodoyeebae may help to transform Confucian ancestor worship into a Christian memorial service. The Christian memorial service is an important instrument for enabling the Christian church to meet the needs of people to express filial piety toward their deceased parents.

To transform Confucian ancestor worship into a Christian memorial service, Christian family members should be 
thoroughly prepared. The writer suggests four steps for a Christian memorial service. Korean churches use several different forms and elements to practice Choodoyeebae. Amongst them, the writer adapts and integrates forms and elements from Ryoo's (2000:206-208) suggestions into the forms and elements which he has practiced in the ministry at his own church. Even though the Christian memorial service is not a new proposal, the writer suggests a form for the service to foster intentional peace and harmony between Christians and non-Christians. His experience has been that nonbelievers participate well in this particular service without exhibiting symptoms of rejection.

The first step is that of intimate preparation. The participant prepares a photograph of the deceased, or if no photograph is available, the name of the deceased may be written on a piece of paper. The photograph or sheet with the name of the deceased is placed on the table or on a high place allowing it to be viewed by everyone in the room. A family member may draft a short biography of the deceased or recount an anecdotal story about the deceased. The family of the deceased and others who attend the memorial service must wear simple clothes. This is an essential attitude in order for Christians to distinguish themselves from the ostentation of typical ancestor worship. Either the preacher or a Christian family member should prepare an insightful message about filial piety or perfect mutual harmony, which provides an opportunity to share the Gospel with nonbelievers.

The second step is to choose an appropriate time and place for the memorial service. Appropriate venues include the family member's home, the cemetery or a churchyard. A convenient time may be selected for all those who would like to attend. Confucian ancestor worship demands the specific time of 12:00 because it is the best time for the souls of the dead ancestors to return to the home, but Christian memorial services do not dictate any specific time or place.

The third step is to make an arrangement of the seats according to Korean manner and custom. The seating arrangement is usually done according to the degree of kinship. In other words, those who are closely related to the deceased will be placed toward the front, along with any persons who are to perform parts of the program such as the persons delivering the prayer and the memorial address.

The fourth step is to proceed with the service as arranged. The following program outline is the suggested structure of a Christian memorial service:

1. The presider gives an opening address, something to the effect that 'We shall now commence a memorial service for the beloved Mr or Ms ...'

2. Confession of faith with the Apostles' Creed.

3. Chanting of hymns - choosing hymns should be given thoughtful consideration with regard to non-believers. This entails the preparation of copies of easy hymns which non-believers can hear once, such as Amazing Grace or Nearer my God to Thee.
4. Prayer for the service given by a person who is designated by family members if possible.

5. Reading of Scriptures by the presider.

6. Sermon by the presider or pastor.

7. Prayer by the presider or pastor.

8. Reading of memorial writing, which is the last injunction of the deceased or a tribute to the memory of the deceased by a family member or a designated person.

9. Chanting of hymns. If the deceased was a Christian, all the participants sing a favourite hymn of the deceased or any other appropriate hymn.

10. Benediction by the pastor. If no pastor is present, the service is concluded with the Lord's Prayer.

After the conclusion of the service, if any non-Christian members or Catholics desire to bow down to the deceased's picture, allow them the opportunity because this bow holds a different meaning from that of the Confucian rite. For them, this bow represents respect and honour to the dead parents. Then, all the participants mutually share the food prepared by the family and partake of fraternal communion in the name of God.

To facilitate the Christian memorial service taking root in Korean society, Korean Christians should perform the teachings of the Bible to the church, ministry and personal lives without compromise. Thus, Korean Christians should be free from severe criticism from non-Christians regarding their ideas that Christianity is a religion that does not teach filial piety.

\section{Conclusion}

As Ryoo (2000:201) points out, Korean Christianity should strive for a reinterpretation of traditional culture in order to develop it for transformation into a familiar Christian ritual comparable to the Confucius and Buddhist rituals in Korea with nonbelievers who understand Christianity as a Western culture. To practice biblical filial piety in Korean society, preachers should be at the centre of reconciliation and education. Robinson (1980) points out that:

the expositor must also be aware of the currents swirling across his own times, for each generation develops out of its own history and culture and speaks its own language. (p. 77)

To teach and to make a wise proclamation of a clear message in this contemporary time, preachers should study the difficulties and conflicts confronted by their audiences, along with the Bible, to grasp the correct meaning of ancestor worship and the filial piety embraced by both Confucianism and Christianity.

Just as Jesus said in John 10 that a good shepherd knows his flock, preachers are concerned with both the Bible and the needs of their audiences for guidance, protection and salvation. As Reu (1967:129) points out, '... preaching is fundamentally a part of the care of souls, and the care of souls involves a thorough understanding of the congregation'. Their messages are based on the Bible and the need to relate 
to the situations confronted by their audiences with regard to the respective cultures in order to facilitate the salvation of lost souls. Just as Kaiser (Shaddix \& Vines 1999:20) defines preaching as 'the biblical emphasis on the practical application of God's Word to the lives of contemporary listeners', preachers possess a sense of obligation for teaching and preaching the truth to their congregations and for guiding them to apply the truth of the Bible to their lives. Dead parents are very valuable to their living descendants, but filial piety should be performed only toward one's living parents just as the Bible teaches to escape the family conflicts that can occur due to Confucian ancestor worship. Ephesians 6:1-3 promises a special blessing to children who practice filial piety toward their living parents, '[c]hildren, obey your parents in the Lord, for this is right.' 'Honor your father and mother' - which is the first commandment with a promise - 'that is may go well with you and that you may enjoy long life on the earth.' A continual consideration for Korean preachers is how to facilitate biblical filial piety as an alternative to allowing Confucian ancestor worship to take root in Korean society as a traditional Korean heritage.

\section{Acknowledgements Competing interests}

The authors declare that they have no financial or personal relationship(s) that may have inappropriately influenced them in writing this article.

\section{Authors' contributions}

This article is based on a dissertation completed for a $\mathrm{PhD}$ degree in the Department of Practical Theology under the supervision of Prof. Dr J.C. Müller.

\section{References}

Adams, D.J., 1995, 'Ancestors, folk religion, and Korean Christianity', in M.R. Mullins \& R.F. Young (eds.), Perspectives on Christianity in Korea and Japan, pp. 95-112, Edwin Mellen Press, New York.

Botterweck, G.J., 1995, Theological dictionary of the Old Testament, vol. 7, transl. D.E. Green, William B. Eerdmans Publishing Co, Grand Rapids.

Brown, J.T., 1969, Among the Bantu nomads, Negro Universities Press, New York.

Chang, L.-S., 1975, 'Evangelization among Buddhists and Confucianists', in J.D. Douglas (ed.), Let the earth hear his voice, pp. 838-839, World Wide Publication, Minneapolis.

Chao, S.H., 1987, 'Confucian Chinese and the Gospel: Methodological considerations', Asia Journal of Theology 1(1), 17-33.

Choi, K., 1988, 'Ancestor worship: From the perspective of Confucianism and Catholicism', in J.Y. Lee (ed.), Ancestor worship and Christianity in Korea, pp. 3543, Edwin Mellen Press, New York.

Confucius, 1997, The analects of Confucius, transl. S. Leys, W.W. Norton \& Co, New York.

Gloer, W.H., 2010, Smyth \& Helwys Bible commentary: 1 \& 2 Timothy-Titus, Smyth \& Helwys Publishing, Mycon.

Kittel, G. (ed.), 1987, Theological dictionary of the New Testament, vols. 2 \& 8, William B. Eerdmans Publishing Co, Grand Rapids.

Lee, J.Y. (ed.), 1988, Ancestor worship and Christianity in Korea, Edwin Mellen Press, New York.

Lee, K.-K., 1987, 'Ancestor worship and kinship structure in Korea', in L. Kendall \& G. Dix (eds.), Religion and ritual in Korean society, pp. 56-70, Institute of East Asian Studies, Berkeley.

Lewis, J.F. \& Travis, W.G., 1991, Religious traditions of the world, Zondervan Publishing House, Grand Rapids.

Oldstone-Moore, J., 2002, Confucianism, Oxford University Press, New York.

Parrinder, G. (ed.), 1983, World religions: From ancient history to the present, Facts on File Publications, New York.

Reu, J.M., 1967, Homiletics: A manual of the theory and practice of preaching, Baker, Grand Rapids.

Ro, B.R. \& Nelson, M.L., 1995, Korean church growth explosion, Word of Life Press, Seoul.

Robinson, H.W., 1980, Biblical preaching: The development and delivery of expository messages, Baker, Grand Rapids.

Ryoo, S.H., 2000, Christian worship and Confucian rite, Soong Sil University, Seoul.

Shaddix, J. \& Vines, J., 1999, Power in the pulpit, Moody Press, Chicago.

Slavicek, L.C., 2002, Confucianism, Lucent Books, San Diego.

The book of filial duty, 1908, transl. I. Chen, John Murray, London.

Thompson, L.G., 1975, Chinese religion: An introduction, Dickenson Publishing Company, San Francisco. 